\title{
EVALUASI PENGGUNAAN ANTIBIOTIK PADA PASIEN PEDIATRIK DENGAN DIARE AKUT DI RUANG RAWAT INAP ANAK
}

\section{EVALUATION OF ANTIBIOTIC USE IN PEDIATRIC PATIENT WITH ACUTE DIARRHEA IN CHILD INPATIENT ROOM}

\author{
Moch Bahtiar Anshory \\ Universitas Perjuangan Tasikmalaya, Indonesia \\ E-mail:muhammadbahtiar95@gmail.com
}

\begin{abstract}
ABSTRAK
Diare akut adalah diare yang onset gejalanya tiba-tiba dan berlangsung kurang dari 14 hari. Sebanyak $40-60 \%$ peresepan antibiotik di Indonesia tidak tepat indikasi, dimana pasien sebenarnya tidak mengalami infeksi akibat bakteri. Pemberian antibiotik yang tidak tepat dapat menyebabkan risiko resistensi dan peningkatan biaya pengobatan. Oleh karena itu dalam penelitian ini akan dilakukan evaluasi penggunaan antibiotik pada pasien pediatrik dengan diare akut di ruang rawat inap RSUD dr. Soekardjo Tasikmalaya. Metode penelitian bersifat deskriptif observasional dengan analisis data dilakukan secara kualitatif berdasarkan Modul Penggunaan Obat Rasional untuk menilai ketepatan penggunaan antibiotik pada pasien anak diare akut. Hasil penelitian ini menunjukkan pasien yang paling banyak menderita diare akut adalah berjenis kelamin laki-laki 31 orang $(54,39 \%)$, penggunaan antibiotik yang paling banyak digunakan adalah Cefotaxim $(66,66 \%)$ dan bentuk sediaan yang paling banyak digunakan adalah injeksi $(72,62 \%)$.Kerasionalan penggunaan antibiotik pada pasien pediatrik dengan diare akut berdasarkan kriteria tepat indikasi $(98,2 \%)$, tepat obat $(98,2 \%)$, tepat dosis $(93 \%)$, tepat pasien $(100 \%)$, tepat waktu pemberian $(98,2 \%)$ dan tepat cara pemberian $(100 \%)$.
\end{abstract}

\section{Kata Kunci : Antibiotik, Diare Akut, Pediatrik}

\begin{abstract}
Acute diarrhea is diarrhea whose onset of symptoms is sudden and lasts less than 14 days. About $40-60 \%$ of the antibiotic prescription is improper indication, where the patient is not actually infected by bacteria. Improper administration of antibiotics can lead to risk of resistance and can lead to increased medical costs. Therefore, this study will evaluate the use of antibiotics in pediatric patients with acute diarrhea in the inpatient room of RSUD Dr. Soekardjo Tasikmalaya. The research method used in this study is descriptive observational with data analysis done qualitatively based on the Rational Drug Use Module to assess the accuracy of antibiotic use in acute diarrhea pediatric patients. The results of this study showed that the most patients suffering acute diarrhea were 31 male $(54.39 \%)$, the most widely used antibiotic was Cefotaxim $(66.66 \%)$ and the most dosage form used was injection (72.62\%) Rationality of antibiotic use in pediatric patients with acute diarrhea based on the proper indication criteria (98.2\%), proper drug $(98.2 \%)$, proper dose (93\%), proper patient (100\%), proper time of administration (98.2\%) and proper method of administration (100\%).
\end{abstract}

Keywords: Antibiotic, Acute Diarrhea, Pediatric 


\section{PENDAHULUAN}

Penyakit diare merupakan penyakit endemis di Indonesia dan juga merupakan penyakit potensial Kejadian Luar Biasa (KLB) yang sering disertai dengan kematian ${ }^{1}$. Tahun 2017 terjadi 21 kali KLB Diare yang tersebar di 12 provinsi, 17 kabupaten/kota. Kabupaten Polewali Mandar, Pohuwato, Lampung Tengah dan Merauke masing-masing terjadi 2 kali KLB. Jumlah penderita 1.725 orang dan kematian 34 orang (CFR 1,97\%). Jawa Barat menempati urutan keenam $(54,22 \%)$ dari 34 provinsi di Indonesia dalam hal cakupan pelayanan penderita diare balita yang berhubungan langsung dengan angka kejadian/insiden rate diare pada tahun 2017 (Kemenkes, 2018) ${ }^{1}$. Kota Tasikmalaya pada tahun 2016 menempati posisi kesebelas $(94,38 \%)$ dari 27 kota ataupun kabupaten yang ada di Jawa Barat dalam hal jumlah penderita diare ${ }^{2}$. Dari data RSUD dr. Soekardjo kota Tasikmalaya tahun 2018 diperoleh data pasien diare sebanyak 916 pasien dengan rincian 631 pasien balita $(68,88 \%), 33$ pasien kanakkanak $(3,60 \%), 35$ pasien remaja $(3,82 \%)$, 53 pasien dewasa $(5,78 \%)$ dan 164 pasien lansia $(17,90 \%)$.

Diare akut adalah penyakit gastrointestinal yang sering terjadi dan salah satu penyebab dehidrasi pada anak-anak ${ }^{3-5}$. Penyakit ini ditandai dengan berlendirnya tinja secara tiba-tiba dalam kurun waktu tiga kali atau lebih dan BAB setiap hari-7. Berdasarkan penyebabnya, diare akut dapat dibedakan sebagai diare akut terkait infeksi dan non-infeksi. Penyebab diare akut terkait infeksi banyak ditemukan pada anak di bawah usia 5 tahun. Mikroorganisme penyebab diare tidak selalu bakteri8-9. Selain bakteri diare dapat disebabkan oleh virus dan parasit.

Prinsip penanganan diare pada anak meliputi 4 hal yaitu rehidrasi, dukungan nutrisi, pemberian obat sesuai indikasi, dan edukasi pada orang tua. Penanganan dan pengobatan lebih ditujukan untuk mencegah dehidrasi, mengatasi dehidrasi yang telah terjadi, mencegah kekurangan nutrisi dengan memberikan makanan selama dan setelahnya, mengurangi lama dan beratnya diare, serta berulangnya episode diare, dengan memberikan suplemen zinc.

Penggunaan antibiotik secara tidak rasional pada diare akut anak masih banyak terjadi di berbagai daerah di dunia ${ }^{10-13}$. Sebanyak 40-60\% peresepan antibiotik di Indonesia tidak tepat indikasi, dimana pasien sebenarnya tidak mengalami infeksi akibat bakteri ${ }^{14}$. Penggunaan antibotik secara empiris jarang diindikasikan pada diare akut infeksi, karena $40 \%$ kasus diare akut infeksi sembuh kurang dari 3 hari tanpa pemberian antibiotik ${ }^{5}$.Untuk itu, penggunaan antibiotik perlu mendapatkan perhatian agar pemakaiannya rasional.

Pemberian antibiotik yang tidak tepat dapat menyebabkan risiko resistensi sedangkan beberapa bakteri penyebab diare sudah resisten terhadap beberapa jenis antibiotik yang ada di Indonesia. Resistensi antibiotik menyebabkan penurunan kemampuan antibiotik tersebut dalam mengobati infeksi. Akibatnya pengobatan menjadi lebih sulit. Penggunaan antibiotik yang tidak bijak menjadi penyebab terjadinya resistensi antibiotik dan dapat meningkatkan biaya pengobatan. Penggunaan antibiotik secara bijak adalah penggunaan antibiotik yang sesuai dengan penyebab infeksi dengan rejimen dosis optimal, lalu pemberian optimal, efek samping minimal, dan dampak minimal terhadap munculnya mikroba resisten ${ }^{15-17}$.

Berdasarkan uraian di atas, maka peneliti merasa perlu untuk melakukan evaluasi penggunaan antibiotik pada pasien pediatrik dengan diare akut di ruang rawat inap RSUD dr. Soekardjo Tasikmalaya.

\section{METODE}

Penelitian ini bersifat deskriptif observasional, yaitu penelitian yang bertujuan untuk mendapatkan gambaran atau deskripsi tentang suatu keadaan secara objektif dan adanya pengamatan (observasi), pengambilan data dilakukan secara prospektif dengan melakukan visite bersama apoteker dan pencatatan data perkembangan kondisi klinis pasien yang 
terdapat dalam rekam medis pasien. Waktu penelitian dilakukan pada bulan Februari s/d Agustus 2019. Penelitian di lakukan di RSUD dr. Soekardjo Tasikmalaya. Teknik pengambilan sampel dilakukan dengan metode purposive sampling, yaitu dengan mengambil sampel berdasarkan kriteria inklusi dan eksklusi.

Adapun yang menjadi kriteria inklusi dalam penelitian ini adalah: 1) Pasien di ruang rawat inap yang terdiagnosis diare akut dengan atau tanpa penyakit penyerta, 2) Pasien yang menjalani rawat inap di RSUD dr. Soekardjo Kota Tasikmalaya, 3) Pasien dengan umur 0-5 tahun, 4) Pasien mendapatkan terapi antibiotik, baik terapi tunggal atau kombinasi, 5) Pasien diare akut yang menggunakan obat oral dan injeksi, 6) Data lengkap yang memuat datadata pasien, meliputi: nomor rekam medik, jenis kelamin, usia, berat badan, suhu, gejala, diagnosis, data penggunaan obat, data laboratorium, lama perawatan dan kondisi pulang. Data rekam medik yang diambil dari bulan Juli-Agustus.

Adapun yang menjadi kriteria eksklusi dalam penelitian ini adalah: 1) Pasien yang menderita diare persisten, yaitu diare yang berlangsung lebih dari 14 hari, 2) Pasien pindah dari ruang rawat inap ke Intensive Care Unit (ICU), 3) Pasien didiagnosis keluar menderita infeksi lain, 4) Data rekam medik pasien yang tidak mengandung antibiotic, 5) Pasien yang pulang paksa.

Jumlah sampel yang digunakan pada penelitian ini adalah 40,96, dimana jumlah tersebut telah dihitung sebelumnya dengan menggunakan rumus Lemeshow. Untuk lebih menambah akurasi data dalam penelitian ini maka penulis mengambil sampel sebesar 60 data rekam medik pasien.

Literatur yang digunakan untuk mengevaluasi penggunaan antibiotik adalah World Health Organization "The Treatment of Diarrhoea", Antibiotic Guidelines, Pharmacotherapy Handbook $9^{\text {th }}$ Edition, Moffet's Pediatric Infectious, Pediatric Drug Doses (2012), Buku Saku Dosis Obat Pediatri (IDAI), World
Gastroenterorology Organization tahun 2012.

Data yang diperoleh dari penelitian ini diolah dengan menggunakan program Microsoft Excel, kemudian disajikan dalam persentase, nilai rata-rata dan tabel. Analisis data dilakukan secara kualitatif berdasarkan Modul Penggunaan Obat Rasional untuk menilai ketepatan penggunaan antibiotik pada pasien anak diare akut. Aspek rasionalitas yang digunakan dalam penelitian ini meliputi tepat indikasi, tepat obat, tepat dosis, tepat pasien, tepat waktu pemberian dan tepat cara pemberian.

\section{HASIL}

A. Karakteristik Pasien

1. Jenis Kelamin

Tabel 1. Distribusi Penggunaan Antibiotik berdasarkan Jenis Kelamin Pasien Pediatrik Diare Akut di Ruang Rawat Inap RSUD dr. Soekardjo

\begin{tabular}{ccc}
\hline $\begin{array}{c}\text { Jenis } \\
\text { Kelamin }\end{array}$ & $\begin{array}{c}\text { Jumlah } \\
(\mathrm{n})\end{array}$ & $\begin{array}{c}\text { Persentase } \\
(\%)\end{array}$ \\
\hline Laki-laki & 31 & 54,39 \\
Perempuan & 26 & 45,61 \\
\hline Total & 57 & 100 \\
\hline
\end{tabular}

2. Usia

Tabel 2. Distribusi Penggunaan Antibiotik berdasarkan Usia Pasien Pediatrik Diare Akut di Ruang Rawat Inap RSUD dr. Soekardjo

\begin{tabular}{lcc}
\hline \multicolumn{1}{c}{ Umur } & $\begin{array}{c}\text { Jumlah } \\
(\mathrm{n})\end{array}$ & $\begin{array}{c}\text { Persentase } \\
(\%)\end{array}$ \\
\hline 0 tahun & 35 & 61,5 \\
(<1 tahun) & & \\
1 tahun & 12 & 21,1 \\
2 tahun & 7 & 12,3 \\
3 tahun & - & - \\
4 tahun & 2 & 3,5 \\
5 tahun & 1 & 1,8 \\
\hline Total & 57 & 100 \\
\hline
\end{tabular}


3. Berat Badan

Tabel 3. Distribusi Penggunaan Antibiotik berdasarkan Berat Badan Pediatrik Diare Akut di Ruang Rawat Inap RSUD dr. Soekardjo

\begin{tabular}{ccc}
\hline $\begin{array}{c}\text { Berat } \\
\text { Badan }\end{array}$ & $\begin{array}{c}\text { Jumlah } \\
\text { Pasien }\end{array}$ & $\begin{array}{c}\text { Persentase } \\
(\%)\end{array}$ \\
\hline $1-5 \mathrm{~kg}$ & 10 & 17,54 \\
$5-10 \mathrm{~kg}$ & 39 & 68,42 \\
$10-15 \mathrm{~kg}$ & 8 & 14,04 \\
\hline Total & 57 & 100 \\
\hline
\end{tabular}

4. Lama Perawatan dan Kondisi Pulang

Tabel 4. Distribusi Penggunaan Antibiotik berdasarkan Lama Perawatan dan Kondisi Pulang Pediatrik Diare Akut di Ruang Rawat Inap RSUD dr. Soekardjo

\begin{tabular}{|c|c|c|c|}
\hline $\begin{array}{c}\text { Lama } \\
\text { Perawat } \\
\text { an }\end{array}$ & $\begin{array}{l}\text { Jumlah } \\
\text { (n) }\end{array}$ & $\begin{array}{c}\text { Persentase } \\
(\%)\end{array}$ & $\begin{array}{l}\text { Kondisi } \\
\text { Pulang }\end{array}$ \\
\hline 1 hari & $\begin{array}{l}5 \\
1 \\
1\end{array}$ & $\begin{array}{l}8,77 \\
1,76 \\
1,76\end{array}$ & $\begin{array}{l}\text { Membaik } \\
\text { Sembuh } \\
\text { Belum } \\
\text { sembuh }\end{array}$ \\
\hline 2 hari & $\begin{array}{c}15 \\
1\end{array}$ & $\begin{array}{c}26,31 \\
1,76\end{array}$ & $\begin{array}{l}\text { Membaik } \\
\text { Sembuh }\end{array}$ \\
\hline 3 hari & $\begin{array}{c}16 \\
5\end{array}$ & $\begin{array}{c}28,07 \\
8,77\end{array}$ & $\begin{array}{l}\text { Membaik } \\
\text { Sembuh }\end{array}$ \\
\hline 4 hari & $\begin{array}{l}6 \\
3\end{array}$ & $\begin{array}{c}10,52 \\
5,26\end{array}$ & $\begin{array}{l}\text { Membaik } \\
\text { Sembuh }\end{array}$ \\
\hline $\begin{array}{l}5 \text { hari } \\
6 \text { hari }\end{array}$ & $\begin{array}{l}3 \\
1\end{array}$ & $\begin{array}{l}5,26 \\
1,76\end{array}$ & $\begin{array}{l}\text { Membaik } \\
\text { Membaik }\end{array}$ \\
\hline Total & 57 & 100 & \\
\hline
\end{tabular}

B. Karakteristik Terapi

1. Jenis Antibiotik

Tabel 5. Distribusi Penggunaan Antibiotik berdasarkan Jenis Antibiotik pada Pasien Pediatrik Diare Akut di Ruang Rawat Inap RSUD dr. Soekardjo

\begin{tabular}{lcc}
\hline $\begin{array}{c}\text { Jenis } \\
\text { Antibiotik }\end{array}$ & $\begin{array}{c}\text { Jumlah } \\
(\mathrm{n})\end{array}$ & $\begin{array}{c}\text { Persentase } \\
(\%)\end{array}$ \\
\hline Cefotaxime & 56 & 66,66 \\
Cefixime & 16 & 19,04 \\
Metronidazole & 9 & 10,71 \\
Ampicillin & 2 & 2,38 \\
Cefadroxil & 1 & 1,19 \\
\hline \multicolumn{1}{c}{ Total } & 84 & 100 \\
\hline
\end{tabular}

2. Bentuk Sediaan

Tabel 6. Distribusi Penggunaan Antibiotik berdasarkan Bentuk Sediaan pada Pasien Pediatrik Diare Akut di Ruang Rawat Inap RSUD dr. Soekardjo

\begin{tabular}{clcc} 
No & $\begin{array}{c}\text { Bentuk } \\
\text { Sediaan }\end{array}$ & Jumlah & $\begin{array}{c}\text { Persentase } \\
(\%)\end{array}$ \\
\hline 1 & Injeksi & 61 & $72,62 \%$ \\
2 & Sirup & 12 & $14,29 \%$ \\
3 & Serbuk & 11 & $13,09 \%$ \\
\hline & Total & 84 & $100 \%$ \\
\hline
\end{tabular}

C. Evaluasi Penggunaan Antibiotik

1. Tepat Indikasi

Tabel 7. Data Evaluasi Penggunaan Antibiotik berdasarkan Tepat Indikasi

\begin{tabular}{lcccc}
\hline \multirow{1}{*}{$\begin{array}{c}\text { Jenis } \\
\text { Antibiotik }\end{array}$} & \multicolumn{2}{c}{ Kategori } & \multicolumn{2}{c}{$\begin{array}{c}\text { Persentase } \\
(\%)\end{array}$} \\
\cline { 2 - 5 } & Tepat & $\begin{array}{c}\text { Tidak } \\
\text { Tepat }\end{array}$ & Tepat & $\begin{array}{c}\text { Tidak } \\
\text { Tepat }\end{array}$ \\
\hline Cefotaxime & 56 & - & 100 & - \\
Cefixime & 16 & - & 100 & - \\
Metronidazole & 9 & - & 100 & - \\
Ampicillin & 2 & - & 100 & - \\
Cefadroxil & - & 1 & - & 100 \\
\hline Total & \multicolumn{3}{c}{84} \\
\hline
\end{tabular}

2. Tepat Obat

Tabel 8. Data Evaluasi Penggunaan Antibiotik berdasarkan Tepat Obat

\begin{tabular}{lcccc}
\multirow{2}{*}{$\begin{array}{c}\text { Jenis } \\
\text { Antibiotik }\end{array}$} & \multicolumn{2}{c}{ Kategori } & \multicolumn{2}{c}{$\begin{array}{c}\text { Persentase } \\
(\%)\end{array}$} \\
\cline { 2 - 5 } & Tepat & $\begin{array}{c}\text { Tidak } \\
\text { Tepat }\end{array}$ & Tepat & $\begin{array}{c}\text { Tidak } \\
\text { Tepat }\end{array}$ \\
\hline Cefotaxime & 56 & - & 100 & - \\
Cefixime & 16 & - & 100 & - \\
Metronidazole & 9 & - & 100 & - \\
Ampicillin & 2 & - & 100 & - \\
Cefadroxil & - & 1 & - & 100 \\
\hline Total & 84 & & & \\
\hline
\end{tabular}

3. Tepat Dosis

Tabel 9. Data Evaluasi Penggunaan Antibiotik berdasarkan Tepat Dosis

\begin{tabular}{cccc}
\hline \multicolumn{4}{c}{ Ketepatan } \\
\hline & Tepat & \multicolumn{3}{c}{ Tidak tepat } \\
\hline $\mathrm{n}$ & $\%$ & $\mathrm{n}$ & $\%$ \\
\hline 53 & 92,9 & 4 & 7,01 \\
\hline
\end{tabular}


4. Tepat Pasien

Tabel 10. Data Evaluasi Penggunaan Antibiotik berdasarkan Tepat Pasien

\begin{tabular}{cccc}
\hline \multirow{2}{*}{$\begin{array}{c}\text { Jenis } \\
\text { Antibiotik }\end{array}$} & Jumlah & \multicolumn{2}{c}{ Ketepatan } \\
\cline { 3 - 4 } & & Tepat & $\begin{array}{c}\text { Tidak } \\
\text { tepat }\end{array}$ \\
\hline Cefotaxime & 56 & $100 \%$ & - \\
Cefixime & 16 & $100 \%$ & - \\
Metronidazole & 9 & $100 \%$ & - \\
Ampicillin & 2 & $100 \%$ & - \\
Cefadroxil & 1 & $100 \%$ & - \\
\hline Total & 84 & & \\
\hline
\end{tabular}

5. Tepat Waktu Pemberian

Tabel 11. Data Evaluasi Penggunaan Antibiotik berdasarkan Tepat Waktu Pemberian

\begin{tabular}{lcccc}
\hline \multicolumn{1}{c}{$\begin{array}{c}\text { Jenis } \\
\text { Antibiotik }\end{array}$} & $\mathrm{n}$ & $\begin{array}{c}\text { Frekuensi } \\
\text { Penggu- }\end{array}$ & & \multicolumn{2}{c}{ Ketepatan } \\
\cline { 4 - 5 } & & $\begin{array}{c}\text { Tean } \\
\text { (daily) }\end{array}$ & & $\begin{array}{c}\text { Tidak } \\
\text { Tepat }\end{array}$ \\
\hline Cefotaxime & 56 & $3 \times 1$ & 100 & - \\
Cefixime & 16 & $2 \times 1$ & 100 & - \\
Metronidazole & 9 & $3 \times 1$ & 100 & - \\
Ampicillin & 2 & $4 \times 1$ & 100 & - \\
Cefadroxil & 1 & $3 \times 1$ & 100 & - \\
\hline
\end{tabular}

6. Tepat Cara Pemberian Tabel 12. Data Evaluasi Penggunaan Antibiotik berdasarkan Tepat Cara Pemberian

\begin{tabular}{|c|c|c|c|c|}
\hline \multirow[t]{2}{*}{ Jenis Antibiotik } & \multirow[t]{2}{*}{$\mathrm{n}$} & \multirow{2}{*}{$\begin{array}{l}\text { Bentuk } \\
\text { Sediaan }\end{array}$} & \multicolumn{2}{|c|}{ Ketepatan } \\
\hline & & & Tepat & $\begin{array}{l}\text { Tidak } \\
\text { Tepat }\end{array}$ \\
\hline Cefotaxime & 56 & $\begin{array}{l}\text { Injeksi vial } \\
\text { (IV) }\end{array}$ & $100 \%$ & - \\
\hline Cefixime & 16 & $\begin{array}{l}\text { Tablet, } \\
\text { Sirup } \\
\text { (per oral) }\end{array}$ & $100 \%$ & - \\
\hline Metronidazole & 9 & $\begin{array}{l}\text { Injeksi/ } \\
\text { Infus (IV) } \\
\text { Sirup } \\
\text { (per oral) }\end{array}$ & $100 \%$ & - \\
\hline Ampicillin & 2 & Injeksi (IV) & $100 \%$ & - \\
\hline Cefadroxil & 1 & $\begin{array}{l}\text { Sirup } \\
\text { (per oral) }\end{array}$ & $100 \%$ & - \\
\hline
\end{tabular}

\section{Evaluasi Ketepatan Penggunaan} Antibiotik

Tabel 13. Evaluasi Ketepatan (Tepat Indikasi, Tepat Obat, Tepat Dosis, Tepat Pasien, Tepat Waktu Pemberian dan Tepat Cara Pemberian) Penggunaan Antibiotik

\begin{tabular}{lcccc}
\hline \multirow{2}{*}{$\begin{array}{c}\text { Kriteria } \\
\text { Ketepatan }\end{array}$} & \multicolumn{2}{c}{ Jumlah } & \multicolumn{2}{c}{ Persentase } \\
\cline { 2 - 5 } & Tepat & $\begin{array}{c}\text { Tidak } \\
\text { Tepat }\end{array}$ & Tepat & $\begin{array}{c}\text { Tidak } \\
\text { Tepat }\end{array}$ \\
\hline Tepat Indikasi & 56 & 1 & 98,2 & 1,8 \\
Tepat Obat & 56 & 1 & 98,2 & 1,8 \\
Tepat Dosis & 53 & 4 & 93 & 7 \\
Tepat Pasien & 57 & - & 100 & - \\
Tepat Waktu & 56 & 1 & 98,2 & 1,8 \\
Tepat Cara & 57 & - & 100 & - \\
\hline
\end{tabular}

\section{PEMBAHASAN}

Berdasarkan hasil penelitian terhadap evaluasi penggunaan antibiotik pada pasien pediatrik dengan diare akut di ruang rawat inap anak RSUD dr. Soekardjo Tasikmalaya periode Juli-Agustus 2019 diperoleh pasien pediatrik yang menderita diare akut adalah 60 pasien. Dari 60 pasien tersebut terdapat 57 pasien yang memenuhi kriteria inklusi.

Penelitian ini telah dilakukan di RSUD dr. Soekardjo Tasikmalaya yang dilaksanakan mulai dari bulan Juli-Agustus 2019. Dimana dari objek penelitian tersebut diperoleh karakteristik/demografi umum pasien pediatrik penderita diare akut yang meliputi penggunaan antibiotik berdasarkan jenis kelamin, usia, berat badan, lama perawatan dan kondisi pulang, jenis antibiotik dan bentuk sediaan.

\section{A. Karakteristik Pasien}

Berdasarkan hasil tabel observasi di ruang rawat inap RSUD dr. Soekardjo berdasarkan jenis kelamin dapat dilihat bahwa jumlah pasien laki-laki lebih banyak menderita diare akut dibanding perempuan. Hasil Penelitian ini sejalan dengan Megawati dan Sari ${ }^{18}$ yang menunjukkan banyaknya pasien anak laki-laki penderita diare yang dirawat di instalasi rawat inap RSUD RAA Soewondo Pati Tahun 2017 dibandingkan dengan anak perempuan dengan perbandingan $52 \%$ pada anak 
laki-laki dan $48 \%$ pada anak perempuan. Hormon estrogen pada perempuan mempengaruhi sintesis IgG dan $\lg A$ menjadi lebih meningkat, dimana peningkatan tersebut yang membuat perempuan kebal terhadap infeksi ${ }^{19}$.

Berdasarkan hasil tabel observasi di ruang rawat inap RSUD dr. Soekardjo berdasarkan usia pasien, diperoleh distribusi usia pasien yang paling banyak menderita diare akut adalah pada umur 0 tahun ( $<1$ tahun) dengan jumlah pasien 35 pasien (61,5\%). Hasil penelitian ini sudah sesuai berdasarkan Riset Kesehatan Dasar (Riskesdas), pasien diare tersebar disemua kelompok umur dengan prevalensi tertinggi terdeteksi pada anak balita (1-4 tahun) yaitu 16,7\%. Begitu pula dengan Survey Demografi dan Kesehatan Indonesia (SDKI), prevalensi diare tertinggi adalah pada anak umur 12-23 bulan, diikuti umur 6-11 bulan dan umur 23-45 bulan'. Hal ini mungkin disebabkan oleh anak pada kelompok umur tersebut mulai aktif bermain dan berisiko terkena berbagai infeksi, termasuk diare ${ }^{20}$.

Pada kelompok umur 0 tahun $(<$ tahun) menempati angka prevalensi tertinggi kedua dengan persentase $16,5 \%{ }^{1}$. Bayi dan anak-anak mudah sakit jika dibandingkan orang dewasa, anak anak lebih rentan terhadap penyakit karena sistem imunnya belum terbentuk dengan sempurna. Banyak faktor yang menyebabkan anak rentan sakit, namun penyebab terbesar adalah adanya infeksi ${ }^{21}$.

Berdasarkan berat badan pasien, mayoritas responden $(68,42 \%)$ yang menderita diare memiliki berat badan 5$10 \mathrm{~kg}$. Dari 39 pasien tersebut, 29 pasien rata-rata berusia $0-11$ bulan (usia 0 tahun). Mengetahui berat badan normal bayi atau balita sesuai dengan usia dan jenis kelaminnya, bisa membantu orang tua memantau tumbuh kembang anak. Berat badan normal balita berusia $0-11$ bulan menurutWHO ada pada rentang $2-10 \mathrm{~kg}^{22}$.
Hasil penelitian dari data lama perawatan dan kondisi pulang, lama perawatan yang dijalani pasien pediatrik diare akut antara 1-6 hari. Mayoritas responden menjalani perawatan selama 3 hari, yaitu 16 orang (28,07\%) dengan kondisi akhir membaik. Jumlah hari rawat tersingkat yaitu 1 hari dialami oleh 5 pasien membaik, 1 pasien sembuh dan 1 pasien belum sembuh. Jumlah hari rawat terlama adalah 6 hari, yaitu pada 1 pasien dengan kondisi akhir membaik.

\section{B. Karakteristik Terapi}

Berdasarkan jenis antibiotik yang sering dijadikan sebagai terapi diare akut adalah Cefotaxime sebanyak 56 obat $(66,66 \%)$. Jumlah 84 adalah item obat yang digunakan pada 57 pasien diare akut yang dijadikan sampel penelitian. Antibiotik yang digunakan sebagai terapi adalah antibiotik golongan penisilin, sefalosporin dan metronidazole. Spektrum antimikroba masing-masing derivat bervariasi. Penisilin merupakan antibiotik dengan spektrum sempit dengan efek samping reaksi alergi akibat hipersensitasi. Sefalosporin merupakan antibiotik dengan spektrum luas yang dapat mematikan bakteri gram positif dan gram negatif ${ }^{23}$.Ampicillin merupakan antibiotik golongan penisilin, sedangkan cefotaxime, cefixime, cefadroxil adalah antibiotik golongan sefalosporin. Metronidazole merupakan antibiotik golongan nitroimidazole.

Penggunaan antibiotik berdasarkan bentuk sediaan adalah sebagian besar diberikan dengan cara injeksi $(72,62 \%)$. Injeksi merupakan bentuk sediaan yang paling sering digunakan. Hal ini dikarenakan ada beberapa antibiotik yang tidak dapat diserap di saluran gastrointestinal sehingga harus diberikan melalui rute pemberian intravena dan intramuskular, seperti antibiotik golongan sefalosporin 24 . Pemberian obat secara intravena di berikan kepada pasien yang sulit menelan obat, pasien tidak sadarkan diri, dan pasien yang mengalami mual 
muntah. Pemberian obat secara intravena lebih efektif dan lebih cepat dibandingkan dengan pemberian obat secara peroral, akan tetapi pemberian obat secara intravena juga ada kekurangannya yaitu timbulnya rasa nyeri, tidak ekonomis dan membutuhkan tenaga medis dalam pelaksanaannya ${ }^{23}$.

\section{Evaluasi Penggunaan Antibiotik}

Penggunaan antibiotik yang rasional pada penelitian ini adalah didasarkan pada 6 kategori, yaitu tepat indikasi, tepat obat, tepat dosis, tepat pasien, tepat waktu pemberian dan tepat cara pemberian.

Berdasarkan data evaluasi tepat indikasi pada pasien pediatrik yang menderita diare akut, antibiotik cefotaxime, cefixime, metronidazole dan ampicillin sudah tepat indikasi, kecuali untuk cefadroxil. Tepat indikasi dilihat dari data diagnosis pasien dan juga dilihat dari kesesuaian antibiotik yang diberikan pada pasien didasarkan pada kemungkinan jenis bakteri penyebab diare akut yang sesuai. Jumlah 84 adalah item obat yang digunakan pada 57 pasien diare akut yang dijadikan sampel penelitian. Daniel et al. (2006) menyatakan bahwa antibiotik golongan sefalosporin generasi ketiga (cefotaxime, cefixime, ceftriaxone), ampicillin dan metronidazole digunakan untuk pasien yang terindikasi mengalami diare akut. Namun untuk cefadroxil digunakan untuk pasien yang terindikasi mengalami infeksi kulit yang disebabkan oleh stafilokokus dan streptokokus ${ }^{25}$.

Tepat obat dilihat dari obat yang dipih harus memiliki efek terapi sesuai dengan penyakit dan merupakan obat pilihan utama (drug of choice).Pemilihan obat yang tepat, yaitu obat yang efektif, aman, dan sesuai dengan kondisi pasien. Penggunaan obat dapat dikatakan tidak tepat atau tidak rasional jika beresiko yang mungkin terjadi lebih besar dibanding dengan manfaat dari ketepatan penggunaan obat.
Terapi antibiotik yang diberikan pada pasien pediatrik yang menderita diare akut untuk kategori tepat obat, semua antibiotik yang diberikan pada pasien telah memenuhi ketepatan obat kecuali cefadroxil. Sejak sefalosporin generasi ketiga memiliki spectrum aktifitas antimikroba yang sangat luas dan sedikit efek sampingnya dibandingkan dengan fluoroquinolon, sefalosporin generasi ketiga telah dipertimbangkan sebagai pilihan obat terbaik untuk pengobatan antibiotik secara empiris pada pasien diare infeksi akut anak ${ }^{26}$.

Cefotaxime dan cefixime merupakan antibiotik golongan sefalosporin generasi ketiga yang menjadi drug of choice untuk pasien diare akut anak (pediatrik). Selain itu juga, Cefotaxime menjadi pilihan utama untuk diare infeksi akut yang disebabkan oleh Yersinia enterocolitica atau $Y$. Pseudotuberculosis 27 .

Cefadroxil digunakan untuk pasien yang terindikasi mengalami infeksi kulit yang disebabkan oleh stafilokokus dan streptokokus ${ }^{25}$. Cefadroxil merupakan golongan antibiotik sefalosporin generasi pertama yang bukan menjadi pilihan utama untuk terapi pada pasien yang mengalami diare akut. Karena antibiotik yang digunakan untuk terapi pada infeksi gasirointestinal tract adalah antibiotik golongan sefalosporin generasi ketiga.

Tepat dosis merupakan pemilihan obat sesuai dengan takaran, frekuensi, pemakaian dan durasi yang sesuai untuk pasien. Ketepatan dalam pemberian dosis antibiotik untuk terapi diare akut sesuai dengan literatur yang digunakan sebagai acuan yaitu Pediatric Drug Doses Second Edition, World Gastroenterology Organization Global Guidelines dan Buku Saku Dosis Obat Pediatri. Berdasarkan hasil penelitian dari 57 kasus diare akut pada pasien pediatrik mayoritas (93\%) menenuhi kriteria tepat dosis. Kasus dengan nomor rekam medik 16979650 dengan berat badan $8,3 \mathrm{~kg}$ di resep obat pasien tertulis Cefotaxime injeksi 3 x 270 mg, 
sedangkan dosis standarnya adalah 100-200 mg/kg/hari, setelah dilakukan perhitungan dosis Cefotaxime injeksi didapatkan hasil bahwa dosis pada pasien tersebut kurang dosis. Selanjutnya pasien dengan no rekam medik 16970649 dengan berat badan $6,5 \mathrm{~kg}$ menerima terapi Cefotaxime injeksi 3 x 200 mg, pasien ini juga mendapatkan terapi dengan dosis yang kurang karena dosis standarnya adalah $100-200 \mathrm{mg} / \mathrm{kg} / \mathrm{hari}$.

Pasien dengan no rekam medik 16971367 dengan berat badan $11 \mathrm{~kg}$ menerima terapi antibiotik dengan dosis yang kurang, di resep nya tertulis Cefotaxime injeksi 3 x 360 mg (100-200 $\mathrm{mg} / \mathrm{kg} /$ hari dosis standar). Lalu pasien dengan no rekam medik 16972105 dengan berat badan $10 \mathrm{~kg}$ menerima terapi ampicillin injeksi dengan dosis $4 \mathrm{x}$ $5 \mathrm{mg}$, sedangkan dosis standarnya adalah 50-250 mg/kg/hari (maks. 2-4 $\mathrm{g} /$ hari), setelah dilakukan perhitungan dosis maka didapatkan hasil bahwa pasien tersebut menerima terapi dengan dosis yang kurang.

Pemberian antibiotik yang tidak tepat dapat menyebabkan risiko resistensi dimana bakteri menjadi lebih kebal dan tahan terhadap beberapa jenis antibiotik. Selain itu juga dapat menyebabkan penurunan kemampuan antibiotik tersebut dalam mengobati infeksi, akibatnya pengobatan menjadi lebih sulit dan biaya pengobatan pun semakin meningkat ${ }^{15-17}$.

Analisis pemberian antibiotik berdasarkan parameter tepat pasien dievaluasi pada pasien yang mendapatkan antibiotik dengan kriteria tepat pasien. Tepat pasien adalah ketepatan pemberian obat yang disesuaikan dengan kondisi pasien ada atau tidaknya kontraindikasi terhadap kondisi pasien. Dalam penelitian ini, tidak terdapat kontraindikasi pada pemberian antibiotik karena dari 57 pasien pediatrik diare akut tidak memiliki riwayat alergi terhadap Cefotaxime, Cefixime, Metronidazole, Ampicillin dan Cefadroxil.
Tepat waktu pemberian dilihat dari frekuensi pemberian obat per hari (daily). Cefotaxime, Cefixime, Metronidazole dan Ampicillin sudah memenuhi kriteria tepat waktu pemberian, namun tidak untuk Cefadroxil. Cefotaxime memiliki frekuensi penggunaan per hari (daily) 2 $x 1$ sehari dan $3 \times 1$ sehari, Cefixime memiliki frekuensi penggunaan per hari (daily) 2 × 1 sehari, Metronidazole memiliki frekuensi penggunaan per hari (daily) $3 \times 1$ sehari, Ampicillin memiliki frekuensi penggunaan per hari (daily) 2 $x 1$ sehari, 3 x 1 sehari dan $4 x$ sehari, sedangkan Cefadroxil memiliki frekuensi penggunaan per hari (daily) 2 x 1 sehari.

Tepat cara pemberian dilihat dari bentuk sediaan obat yang diberikan atau diresepkan pada pasien (misalnya injeksi, serbuk, sirup). Berdasarkan evaluasi penggunaan antibiotik berdasarkan tepat cara pemberian mendapatkan hasil $100 \%$ tepat cara pemberian. Cefotaxim mempunyai bentuk sediaan injeksi vial. Cefixim mempunyai bentuk sediaan tablet dan sirup. Metronidazol mempunyai bentuk sediaan injeksi/infus, tablet, kapsul, dan sirup. Ampicillin mempunyai bentuk sediaan injeksi, tablet, kapsul, suspensi dan drop. Cefadroxil mempunyai bentuk sediaan tablet, kapsul dan sirup.

Evaluasi pengunaan antibiotik berdasarkan ketepatan (tepat indikasi, tepat obat, tepat dosis, tepat pasien, tepat waktu pemberian dan tepat cara pemberian) diperoleh hasil tepat indikasi $98,2 \%$, tepat obat $98,2 \%$, tepat dosis $93 \%$, tepat pasien $100 \%$, tepat waktu pemberian $98,2 \%$ dan tepat cara pemberian $100 \%$.

\section{SIMPULAN DAN SARAN}

Berdasarkan penelitian yang dilakukan di ruang rawat inap anak RSUD dr. Soekardjo yang lebih banyak menderita diare akut adalah jenis kelamin laki-laki mencapai $54,39 \%$, umumnya menggunakan antibiotik 
Cefotaxim (66,66\%) dengan bentuk sediaan obat injeksi $(72,62 \%)$.

Kerasionalan penggunaan antibiotik pada pasien pediatrik dengan diare akut berdasarkan kriteria tepat indikasi $(98,2 \%)$, tepat obat $(98,2 \%)$, tepat dosis $(93 \%)$, tepat pasien $(100 \%)$, tepat waktu pemberian $(98,2 \%)$ dan tepat cara pemberian (100\%).

\section{UCAPAN TERIMAKASIH}

Ucapan terima kasih yang sebesarbesarnya penulis sampaikan kepada :

1. Kepala Instalasi Farmasi RSUD dr. Soekardjo.

2. Direktur Poltekkes Kemenkes Tasikmalaya.

3. Ketua Program Studi D III Farmasi Poltekkes Kemenkes Tasikmalaya.

4. Dekan Fakultas IImu Kesehatan Universitas Perjuangan Tasikmalaya.

5. Ketua Program Studi S1 Farmasi Universitas Perjuangan Tasikmalaya.

6. Dosen Pembimbing dari kampus dan rumah sakit.

\section{DAFTAR PUSTAKA}

1. Kemenkes RI. Profil Kesehatan Indonesia Tahun 2017, Jakarta: Kementerian Kesehatan RI ; 2018.

2. Dinkes Provinsi Jawa Barat, Profil Kesehatan Provinsi Jawa Barat Tahun 2016, Bandung: Dinas Kesehatan Provinsi Jawa Barat ; 2017.

3. Guandalini S, Kahn SA. Acute diarrhea In: Kleinman RE, Sanderson IR, Goulet $O$, Sherman PM, Mieli-Vergani G, Shneider B, editors. Walker's Pediatric Gastrointestinal Disease.5th ed. Hamilton: BC Decker Inc;2008. p.64253.

4. Koletzko S, Osterrieder S. Acute infectious diarrhea in children. Dtsch Arztebl Int; 2009.

5. Farthing $M$, Salam MA, Lindberg $G$, Dite P, Khalif I, Salazar-Lindo E. Acute diarrhea in adults and children: a global perspective. J Clin Gastroenterol, World Gastroenterology Organization ; 2013.
6. Bhutta ZA. Gastroenteritis in children. In: Kliegman RM, Stanton BF, Schol NF, St Geme III JW, Behrman RE, editors. Nelson Textbook of Pediatrics. 19th ed. Philadelphia: Elsevier; 2011. p. 39-1323.

7. Guarino A, Albano F, Ashkenazi S, Gendrel D, Hoekstra JH, Shamir R, et al. Nutrition/European Society for Paediatric Infectious Diseases evidence-based guidelines for the management of acute gastroenteritis in children in Europe. European Society for Paediatric Gastroenterology, Hepatology; J Pediatr Gastroenterol Nutr; 2008. p. 81-122.

8. Bonkoungou IJO, Haukka K, Österblad $M$, et al. Bacterial and viral etiology of childhood diarrhea in Ouagadougou, Burkina Faso. BMC Pediatr; 2013.

9. Moyo SJ, Gro N, Matee MI, et al. Age specific aetiological agents of diarrhoea in hospitalized children aged less than five years in Dar-es-Salaam, Tanzania. BMC Pediatr, 2011.

10. Muraduzzaman AKM, Rashed-UI Islam SM, Mahmudur Rahman Siddiqui. Use of drugs and treatment cost in acute watery diarrhoea of under-2 children attending a tertiary hospital of Bogra. $J$ Med ; 2013.

11. Lafta RK, AI-Shatari SAE HR. Drug Misuse in the treatment of diarrhea Among Children under Five Years: A Sample from Baghdad. Iraqi $J$ Community Med ; 2014.

12. Kotwani A, Chaudhury RR, Holloway K. Antibiotic-prescribing practices of primary care prescribers for acute diarrhea in New Delhi, India. Value Health ; 2012.

13. Zwisler G, Simpson E, Moodley M. Treatment of diarrhea in young children: results from surveys on the perception and use of oral rehydration solutions, antibiotics, and other therapies in India and Kenya. J Glob Health ; 2013.

14. Menteri Kesehatan RI. PERMENKES RI Nomor 2406. Jakarta: Kementerian Kesehatan Republik Indonesia; 2011.

15. Kemenkes RI. Penggunaan Antibiotik Bijak dan Rasional Kurangi Beban Penyakit Infeksi.Kementerian Kesehatan RI. 2015 [cited 3 Maret 
2018]. Available from : http://www.depkes.go.id/pdf/pengguna an-antibiotik-bijak dan rasional-kurangibeban-penyakit-infeksil

16. Permenkes RI. Peraturan Menteri Kesehatan Republik Indonesia Nomor 340 tahun 2010 tentang Klasifikasi Rumah Sakit. Jakarta: Menteri Kesehatan Republik Indonesia ; 2010.

17. Sukandar, E.Y., Andrajati, R., Sigit, J.I., Adnyana, I.K., Setiadi, A.A.P., dan Kusnandar. Gangguan Pencernaan: ISO Farmakoterapi 1. Jakarta: PT. ISFI Penerbitan ; 2011.

18. Megawati dan Sari. Rasionalitas Penggunaan Antibiotik untuk Pengobatan Diare pada Pasien Anak di Instalasi Rawat Inap RSUD RAA Soewondo Pati Tahun 2017. Kudus : ELibrary STIKES Cendekia Utama Kudus Vol. 2 No. 1 ; 2018.

19. Radji. M. Human Immunodeficiency Virus. In: Imunologi dan Virologi. PT.ISFI: Jakarta ; 2010.

20. Kemenkes RI. Modul Penggunaan Obat Rasional. Jakarta: Kementerian Kesehatan RI ; 2011

21. Triasmara, W.12 Cara Agar Balita Tidak Mudah Sakit. 2013 [cited 30 Juli 2019]. Available from: http://kesehatan.kompasiana.com/ibudan - anak/2013/09/04/12 - cara -agar balita - tidak - mudah - sakit - 589590. html.

22. Fitriyani. Cek Perkembangan berat badan bayi anda agar sesuai panduan WHO.2018. [cited 31 Juli 2019]. Available from https://id.theasianparent.com/beratbadan-normal-bayi/am

23. Utami. Evaluasi Penggunaan Antibiotik Untuk Penyakit Diare Pada Pasien Pediatri Rawat Inap Di Rsud "X" Tahun 2011. [Skripsi]. Universitas Muhammadiyah Surakarta ; 2012. 